\title{
Microbial life in the phyllosphere
}

\section{Journal Article}

\section{Author(s):}

Vorholt, Julia A.

Publication date:

2012-12

\section{Permanent link:}

https://doi.org/10.3929/ethz-b-000059727

Rights / license:

In Copyright - Non-Commercial Use Permitted

Originally published in:

Nature Reviews Microbiology 10(12), https://doi.org/10.1038/nrmicro2910 


\title{
Microbial life in the phyllosphere
}

\author{
Julia A. Vorholt \\ Institute of Microbiology, ETH Zurich, Switzerland \\ julia.vorholt@micro.biol.ethz.ch
}

Our knowledge of the microbiology of the phyllosphere, or the aerial parts of plants, has historically lagged behind our knowledge of the microbiology of the rhizosphere, or the below ground habitat of plants, particularly with respect to fundamental questions such as which microorganisms are present and what do they do there. In recent years however, this has begun to change. Cultivation-independent studies have revealed that a few bacterial phyla predominate in the phyllosphere of different plants and that plant factors are involved in shaping these phyllosphere communities, which feature specific adaptations and exhibit multipartite relationships both with host plants and among community members. Insights into the underlying structural principals of indigenous microbial phyllosphere populations will help to develop a deeper understanding of the phyllosphere microbiota and will have applications in plant growth promotion and protection.

Plants are populated by microorganisms both below and above ground. The phyllosphere (Fig. 1) ${ }^{1}$ comprises the aerial parts of plants and is dominated by the leaves. The leaf surface habitat is vast: vegetation modelling ${ }^{2}$ resulted in an estimated global leaf area of $508,630,100 \mathrm{~km}^{2}$, which corresponds to $1,017,260,200 \mathrm{~km}^{2}$ of upper and lower leaf surface and is an area approximately twice as great as the land surface. Assuming that there are on average $10^{6}$ to $10^{7}$ bacteria per $\mathrm{cm}^{2}$ leaf surface ${ }^{3}$, the global bacterial population present in the phyllosphere could comprise up to $10^{26}$ cells. The total size of the fungal population has not yet been estimated, but is expected to be lower[au: ok? $]^{3,4}$.

Annual plants complete their life cycle within a single growth season, perennial deciduous plants synchronously form and shed leaves every year, and evergreen plants do so sequentially. Consequently, the phyllosphere can be considered an ephemeral or short-lived environment as opposed to the rhizosphere, which comprises the area in the soil around plant roots [au: ok?]. 
Successful phyllosphere inhabitants can be expected to multiply and occupy newly formed niches while the leaves are expanding. Microbial epiphytes are exposed to the atmosphere and are subjected to the diurnal cycle; they are influenced directly by sunlight and indirectly by plant metabolism. Furthermore, the hydrophobic waxy cuticle that covers plant epidermal cells reduces evaporation of water as well as leaching of plant metabolites, thus resulting in an oligotrophic environment.

Despite these unifying aspects, there is substantial environmental heterogeneity at the macro- and microscale. At the macroscale, factors such as climatic conditions, the location of leaves within the vegetation and the chemical composition of the cuticle affect the environment. On the microscale, the presence of veins, stomata and surface appendages, including trichomes and hydathodes, alter nutrient availability ${ }^{5,6}$. As well as nutrient limitation, microorganisms must also deal with UV radiation and low or fluctuating water availability and, as a consequence, are often unevenly distributed on the leaf surface and multiply unevenly ${ }^{7}$. In addition to both predictable and unpredictable environmental variability the microbial inhabitants of the phyllosphere also encounter antimicrobial compounds produced by plants or other microorganisms. Moreover, they can enter the apoplast (such microorganisms are then sometimes referred to as endophytes) where they trigger a range of plant defence responses. Phytopathogens can counteract such responses through the transfer of effectors ${ }^{8}$. An epiphytic lifestyle predominates in commensal phyllosphere bacteria [au: just bacteria?]; however, it also represents the initial phase of foliar colonization by many phytopathogens. In the case of bacterial pathogens, this phase precedes entry into the leaves via natural openings such as stomata or hydathodes and the onset of disease $e^{9,10}$, or follows egress from the inner part of the leaf to the surface $^{11}$.

Although the phyllosphere has been less intensively studied than the rhizosphere, it has received considerable attention in recent years, and interest in the microbiology of leaf surfaces is now acknowledged to extend beyond pathogens. This review highlights recent cultivation-independent and -dependent studies that survey the microbial inhabitants of the phyllosphere and indicate conserved mechanisms by which predominating groups cope with the challenges of life on the leaf surfaces of terrestrial plants. 


\section{Microbial phyllosphere communities}

Several recent cultivation-independent studies have revealed insights into the composition of microbial phyllosphere communities. It is apparent that these communities do not represent random assemblies of microorganisms, but instead undergo selection that results at least partially in predictable microbial communities with relatively few dominant (sub-)phyla ${ }^{12-18}$. This conclusion is derived from evaluations of the community composition with respect to plant host species as well as temporal and spatial factors. Most studies on the identity of organisms in the phyllosphere have focused on bacteria and, to a lesser extent, on fungi; archaea are apparently not abundant in the phyllosphere ${ }^{12,17,19}$.

Bacterial aggregates. Most bacteria on leaf surfaces do not occur as solitary cells or small groups of cells as fungi tend to $\mathrm{do}^{20}$, but in larger aggregates ${ }^{21}$; particularly at the depressions formed at the junctions of epidermal cells, along the veins and at the bases of trichomes ${ }^{3,4,22}$ (Fig. 1) where they are generally embedded within extracellular polymeric substances (EPS) ${ }^{3,4}$. The EPS helps maintain a hydrated surface around the bacteria and eventually also to concentrate detoxifying enzymes (see below). Using experimental inoculations with a bacterial model strain and observations by epifluorescence microscopy suggests that most bacteria are located in aggregates of 1,000 cells or more and that the size of the aggregate positively correlates with water availability ${ }^{22}$. Aggregates usually contain a variety of bacterial and eventually also fungal species ${ }^{4}$. How these aggregates form, and the contributions of local replication and relocation, are key questions that remain to be addressed in further detail at the microscale ${ }^{23,24}$. Notably, initial investigations using a bacterial dual-species model system have shown that different bacteria segregate in space to different extents ${ }^{25}$.

Community composition. For the past 15 years, 16S/18S-ribosomal RNA gene PCR amplification followed by sequencing of clone libraries or, more recently, amplicon pyrosequencing, has been the most common approach by which the composition of the microbial phyllosphere communities has been analysed (see e.g. ${ }^{16-18,26}$ ). Overall, species richness in phyllosphere communities is high. It appears fungal communities are extremely variable in the phyllosphere in temperate regions and 
exhibit even greater diversity in the phyllosphere of tropical trees ${ }^{16,27}$. The bacterial species richness is substantial in both temperate and in particular in the subtropical and tropical regions ${ }^{12,15,18,19,28}$; however, the bacterial communities are lower [au: do you mean community size is smaller (total number is less) or community diversity is reduced (fewer species)?]compared to the rhizosphere or bulk soil, as evidenced by rarefaction analysis ${ }^{12,19}$. This is not surprising, given that leaves usually have a relatively short lifespan and are discrete entities, in contrast to the roots which are surrounded by soil where microorganisms can survive in a dormant state for many years or even decades. Some bacterial phyla such as the Proteobacteria (and among them in particular Alphaproteobacteria and Gammaproteobacteria) have been shown to be predominant in the phyllosphere of distinct plant species using various PCR methods ${ }^{13,26}$. Metagenomic shotgun sequencing of total genomic DNA extracted from environmental samples is an alternative approach that generates taxonomic information based on single copy protein-coding marker genes. Although extraction and sequencing protocols are also prone to biases, metagenome shotgun sequencing avoids the PCR amplification biases that result from the use of target-specific primers ${ }^{29}$. Figure. 2 shows the results of an MLTreeMap analysis ${ }^{30}$ from four different phyllosphere samples: the dicots Glycine max (soybean), Trifolium repens (clover) and Arabidopsis thaliana and the monocot Oryza sativa (rice) ${ }^{12,19}$. Proteobacteria was the most represented phylum, with the Alphaproteobacteria representing up to $70 \%$ of the community in each of the four phyllosphere samples. Of these, Methylobacteriaceae were found in all four samples and Sphingomonadaceae was the most abundant bacterial family detected on the three dicot plants. In addition to the Proteobacteria, the Bacteroidetes phylum was abundant in the soybean, clover and A. thaliana communities, but constituted only a minor fraction of the rice sample. By contrast, Actinobacteria accounted for $\sim 40 \%$ of the rice community but constituted a lower fraction of the other samples. The most frequently detected genera are listed in Table 1; some bacterial genera are recurrently found on different plants although their relative contribution to the overall community might differ. Some of these genera such as Agrobacterium, Burkholderia, Clavibacter, Leifsonia, Pantoea, Pseudomonas and Xanthomonas include phytopathogenic bacteria. Comprehensive cultivation-independent studies paired with strain isolation has also allowed the identification of representative bacterial strains of various genera including Pseudomonas, Xanthomonas, Pantoea, 
Dadantii, Methylobacterium and Sphingomonas ${ }^{31-36}$, as well as fungal model strains such as the yeastlike fungus Aureobasidium pullulans ${ }^{37}$, for functional studies (see further below).

Another interesting aspect is that at the genus or order rank, there is a relatively high consistency in the bacterial phyllosphere communities (Fig. 2); however, at a greater phylogenetic resolution, remarkable differences can be observed; for example, at the strain level, community profiling shows striking differences between plants of different species growing adjacent to each other (see for example $\left.{ }^{12,38}\right)$.

Drivers of community structure. What drivers shape microbial communities is a fundamental question in microbial ecology. For the phyllosphere, it is well established that environmental factors, including radiation, pollution and nitrogen fertilization, as well as biotic factors, such as leaf age and the presence of other microorganisms, affect bacterial community structure ${ }^{39-42}$ and eukaryotic microbial diversity is probably influenced by the same factors ${ }^{43,44}$. Although the identification of assembly rules for bacterial and fungal communities is very difficult due to the complexity of the abiotic and biotic factors and stochastic events involved, several recent studies have reported that the plant genotype is an important factor influencing the bacterial composition of the phyllosphere. Redford et al. analyzed the bacterial community composition in the phyllosphere of pine trees and found that intra-plant species variability was lower than inter-plant variability, even over large geographical distances ${ }^{45}$. Similarly, a significant but weak association between tree species and phyllosphere communities have been described for tropical trees ${ }^{18}$. Another study focused on members of the ubiquitous plant colonizing genus Methylobacterium in the phyllosphere of A. thaliana plants under natural conditions and also found that intra-plant variability was lower than inter-plant variability, although the site was also identified as an important factor that influenced this variability ${ }^{38}$. Pronounced site effects were also found for bacterial and fungal communities of the salt-excreting Tamarix tree $^{17}$, as well as bacterial communities on field-grown lettuce ${ }^{26}$ as shown by comprehensive amplicon sequencing. Other studies have focused on the effect of plant genotypes and involved field trials with a collection of A. thaliana and maize plants (accession and selected plant mutants) and indicate that plant factors shape the bacterial phyllosphere community structure; possible mechanisms for such genotype effects 
might originate from leaf surface properties ${ }^{46}$, hormone jasmonic acid signaling ${ }^{47}$ or signaling via the gamma-aminobutyric acid (GABA) pathway ${ }^{48}$. The identification of plant genes crucial to the microbial composition of the phyllosphere will be of greatest interest in future studies and help elucidate whether plants have evolved to actively recruit these communities. This has been suggested for the rhizosphere ${ }^{49,50}$, and was further substantiated by recent in-depth analyses of the root associated microbiota, demonstrating that a small fraction of root endophytes varies between plants of different genotype $^{51,52}$. Plants may also recruit founder or keystone species that play a fundamental role in structuring the overall community through microbe-microbe interactions. The finding that numerous bacterial genera on one plant species were represented on neighbouring plants by different strains ${ }^{12,38}$ indicates that plants offer distinct niches to different strains of the same bacterial genus and may thus contribute to intra-genus variation.

Origin of community members. Another basic question relates to the source of phyllosphere microorganisms. The finding that bacterial populations re-establish on annual plants in patterns similar to those seen in previous years ${ }^{38}$ argues for local reservoirs of bacteria. Although a fraction of microorganisms in the phyllosphere can be expected to be ad-hoc colonizers from the air, for bacteria at least, 16S-rRNA gene based profiling suggest that early recruitment of a 'core' community from seeds, the soil or other plants could explain the inter-annual consistency in the dominant bacterial community members on individual plants ${ }^{38}$. While seed-born transmission has been documented for Xanthomonas spp..$^{53}$, a lack of knowledge of the relative contribution of microorganisms from different sources to the developing phyllosphere community makes it difficult to draw general conclusions. Dedicated analyses will be required to elucidate the relative contribution of vertical and horizontal transmission [au: examples of each?].

\section{Microbial adaptation to the phyllosphere}

Successful reproduction in the phyllosphere requires adaptation to this habitat, including the ability to withstand abiotic and biotic stresses such as scarce nutrient supply and the presence of anti-microbial secondary metabolites of plant or microbial origin. Phyllosphere-inhabiting bacteria can be expected to 
share common strategies in addition to genotype[au: species?]-specific strategies to survive these stresses. The identification of traits that are important for survival and the elucidation of their molecular basis is not an easy task, and it has been suggested that many different traits contribute incrementally to epiphytic fitness ${ }^{54}$. Gene-expression studies including transcriptomic and proteomic analyses have helped to identify genes and protein families that are upregulated upon plant colonization using various biological model systems (Table 2). These data serve as a proxy by which to identify the bacterial protein functions that are required for survival in the environment. Additionally, meta (or community) proteogenomic approaches allow the identification of abundant proteins in microbial community members which can help infer their in planta physiology ${ }^{12,19}$ and stimulate targeted analysis of individual proteins or protein families to elucidate their importance.

The following section focuses on general traits of non-pathogenic bacteria and pathogenic bacteria in their epiphytic phase (Fig. 3). However, it should be kept in mind that the type-III secretion system (T3SS) of phytopathogenic bacteria is also crucial to attain a maximal epiphytic population size $\mathrm{e}^{9,55}$. In this context it is interesting to note that the importance of specific effectors for the development of aggregates on leaf surfaces was recently demonstrated for Pseudomonas syringae B728a and was shown to be mediated by a subpopulation of the epiphytic population and be host-dependent ${ }^{56}$ [au: ok?]. Moreover, bioactive molecules produced by Pseudomonas strains such as coronatine ${ }^{57}$ or syringolin $\mathrm{A}^{58}$ counteract pathogen-triggered stomata closure and thus affect entry into the apoplast.

Resistance to abiotic stresses. The phyllosphere is exposed to oxygen from plant photosynthesis and also to light during the day. Consequently, microbial colonizers are particularly prone to reactive oxygen species (ROS)-mediated direct damage of DNA and indirect damage to proteins. Protection mechanisms that have been shown experimentally to be important in bacterial epiphytic fitness involve the production of pigments ${ }^{59}$ and the activation of DNA-repair mechanisms, which include but are not limited to, photolyases ${ }^{60}$. Additionally, the DNA-protection protein Dps is important in stress protection and is present in high amounts during phyllosphere colonization ${ }^{12,61}$. Catalases and superoxide dismutases can also detoxify ROS. 
Desiccation is another environmental factor that is of relevance in the phyllosphere ${ }^{62}$. Two principal traits are known to help bacteria cope with this challenge, aggregate formation and the excretion of bioactive compounds. The importance of aggregate formation was demonstrated by analyzing the survival of solitary versus aggregated P. syringae cells on bean-leaf surfaces that were periodically exposed to desiccation stress and humid conditions ${ }^{63}$. Aggregation involves the formation of EPS, which helps in maintaining a highly hydrated layer surrounding the bacteria and contributes to epiphytic fitness ${ }^{64-66}$. In addition, biosurfactants that increase wettability are commonly found to be secreted by phyllosphere bacteria ${ }^{67,68}$. Not only is sufficient water availability a crucial parameter, but fluctuations in water availability result in osmotic stress, as has been illustrated on the microscale through the use of bacterial bioreporters ${ }^{69}$. Pseudomonas spp. and other epiphytes can protect themselves against osmotic stress by accumulating compatible solutes such as choline or trehalose, either by de novo synthesis or by importing plant-derived osmoprotectants ${ }^{70,71}$.

Resistance to (and production of) antimicrobial compounds. Plants produce a wide range of structurally diverse secondary metabolites with antimicrobial activity ${ }^{72}$. Additionally, antimicrobial compounds might be produced by microorganisms and thus be involved in structuring the community in planta at the local scale. Numerous bacteria produce antibiotics under laboratory conditions; however, the significance of their production in planta is not well established, with very few exceptions (e.g., $\left.{ }^{73}\right)$. The relevance of mechanisms to counteract toxic compounds in situ is shown by the finding that resistance-nodulation-cell division (RND) efflux pumps of plant-pathogenic P. syringae pathovars are crucial for in planta reproduction and evading the native immune response $^{74,75}$.

Motility versus adhesion. Motility allows active movement to favourable sites on leaf surfaces and is likely to be assisted by chemotaxis towards nutrients or plant signalling molecules. Pseudomonas model strains have been shown to dynamically regulate motility in response to various endogenous and exogenous signals, including quorum-sensing molecules (Box 1). Motility might thus help Pseudomonas strains to search for more favourable sites, to facilitate spreading and also to locate their 
ultimately preferred site, the leaf apoplast, where high growth rates of phytopathogens have been observed $^{10,76}$. The degree to which the motility of commensal bacteria is of importance for epiphytic fitness is currently not clear. Notably, no evidence for flagellin production has been found so far in commensal phyllosphere members in planta ${ }^{12}$, provoking the question whether commensals suppress the expression of the genes involved in flagellum formation. Downregulating flagellin synthesis favours local aggregate formation and might prevent plant recognition of Flg22, a conserved peptide in flagella and a well-described microbial associated molecular pattern (MAMP) that is recognized by the plant immune receptors ${ }^{8}$. Adhesion and local replication, on the other hand, might represent the dominant lifestyle of commensal bacteria that are generally found as epiphytes on leaf surfaces and to a lesser extent in the apoplast ${ }^{10,34}$. Adhesion is likely to favour resistance to removal by rain fall and splash from rain drops and is a prerequisite for the formation of EPS-containing mucus that provides protection from desiccation. Consequently, adhesion may favour successful epiphytic colonization and allow colonization following leaf expansion.

So far, few studies have addressed the presence of surface structures and specific proteins that allow adhesion to the hydrophobic cuticle. Notable exceptions include studies on adhesion by the hemagglutinin family proteins in Dickeya dadantii (formerly Erwinia chrysanthemi) and Xanthomonas strains, which have been shown to be important for epiphytic attachment and aggregation in these species $^{77,78}$.

Metabolic adaptation. In contrast to the rhizosphere, where large quantities of plant assimilates are accessible to microorganisms, nutrients on leaf surfaces are scarce ${ }^{3}$. Carbon sources that have been identified on leaf surfaces include carbohydrates, amino acids, organic acids, and sugar alcohols ${ }^{79-81}$. The heterogeneous nature of the nutrient availability on leaf surfaces has been well documented by studies using bioreporters ${ }^{5,6,82}$. It is currently not clear whether leaf-surface waxes support microbial growth. Bacteria themselves may influence substrate availability by the production of biosurfactants that result in increased wettability and thus increased substrate leaching ${ }^{68}$. Additionally, bacteria (and fungi) may also produce plant hormones, including indole-3-acetic acid (IAA; also known as auxin), (see e.g. ${ }^{36,83,84}$ ). There is evidence, that auxin increases nutrient availability by stimulating cell wall 
loosening and release of saccharides from the plant cell wall ${ }^{3,85}$. The higher substrate availability as a result of bacterial auxin production is substantiated by epiphytic fitness tests ${ }^{83}$.

In addition to the above-mentioned carbon sources, there are other, volatile plant-derived substrates including isoprenes and one carbon compounds ${ }^{86}$. A prominent one carbon source is methanol, which is primarily formed as a by-product of cell wall metabolism by pectin methyl esterases and is released in diurnal cycles ${ }^{86}$. The global emission of plant-produced methanol has been estimated to be $10^{14} \mathrm{~g}$ per year ${ }^{87}$. Methanol has been documented as a substrate for epiphytic bacteria and methylotrophic yeasts, conferring a growth advantage in situ ${ }^{88-90}$. Notably, essentially all methylotrophic bacteria in the phyllosphere belong to the genus Methylobacterium and are facultative methylotrophs with a restricted substrate range ${ }^{32,91}$. Besides methanol, it has been documented that plants produce halogenated methane derivatives ${ }^{92}$. Methyl chloride-degrading Alphaproteobacteria of the genus Hyphomicrobium have been isolated from the phyllosphere ${ }^{93}$ although the significance of this one-carbon substrate for epiphytic fitness requires further investigation. Yet another one carbon compound that has been postulated to be produced at trace amounts is photochemically formed methane ${ }^{94}$. However, there is so far no evidence that methane formation by plants can sustain a population of methanotrophs and they do not appear as abundant players in the microbial community in the phyllosphere of rice plants ${ }^{19}$.

Carbon-source phenotyping of bacteria under laboratory conditions is a standard method applied to phyllosphere bacteria and is frequently used to determine the overlap in substrate utilization among strains as a measure of their potential to co-exist ${ }^{95,96}$. An extension of such carbon profiling was recently performed ${ }^{97}$; apoplastic fluid extracted from healthy tomato leaves was used to preincubate P. syringae before recording the repertoire of nutrients that could be consumed without further preadaptation of the cells. Such substrate profiles revealed that $P$. syringae uses a restricted number of sugars, organic acids and amino acids.

Gene-expression profiling in situ is an alternative approach to investigate the metabolic adaptations of particular microorganisms ${ }^{12,61}$. The high abundance of enzymes involved in methylotrophy of Methylobacterium spp. is in-line with the importance of these proteins in the physiological adaptation to, and methanol consumption in, the phyllosphere ${ }^{88,90}$. The presence of 
numerous ABC transporters from Pseudomonas spp., including those involved in the uptake of monoand disaccharides and amino acids suggests the uptake of these substrates by these species. The production of a large number of TonB-dependent transport systems by Sphingomonas strains may indicate scavenging of various nutrients present at low concentrations. This finding corroborates an earlier report on the importance of the TonB-dependent transporter for sucrose uptake and metabolism in Xanthomonas spp. ${ }^{98}$. To gain further insight into metabolic activities of epiphytic communities it will be necessary to develop in situ metabolomic approaches for epiphytic bacteria; although this will be challenging it is likely to offer new insights into the physiology of these bacteria.

There is evidence that bacterial communities on well-fertilized plants are limited primarily by carbon availability and only secondarily by nitrogen availability ${ }^{96}$. Bacteria can use several nitrogen sources including organic nitrogenous compounds such as amino acids which may represent a valuable source of nitrogen for phyllosphere bacteria. In addition, ammonia is probably used as a nitrogen source in the phyllosphere ${ }^{12,99}$, and nitrogen fixation has been reported by phyllosphere bacteria $^{100}$.

Aside from carbon and nitrogen, phyllosphere bacteria require further macro- and also microelements for growth. The expression of several transport systems for phosphate, sulfate and iron has been observed in situ ${ }^{12,61,101}$. Although several studies found that siderophore production was involved in epiphytic growth and competition with other microorganisms during colonization of leaf surfaces, others found only moderate or no iron limitation ${ }^{102,103}$. Such controversial results were recently suggested to be a consequence of plant secondary metabolism, as different plants produce various polyphenolic compounds (including tannins) with different iron-sequestering abilities ${ }^{104}$. Thus, the importance of siderophore production for iron sequestration may depend on the host plant.

Recent studies have reported that phyllosphere bacteria that have the potential to benefit from light by expressing bacteriorhodopsins and the presence of aerobic anoxygenic phototrophs that may be able to capture light in photosynthetic reaction centers ${ }^{105,106}$. Light-harvesting in the phyllosphere would allow epiphytic bacteria to use light as an additional energy source and might supply maintenance energy in case of nutrient deficits. 
Regulation of fitness traits. Uncovering global and specific regulatory systems as well as the perceived environmental cues, will be crucial for understanding microbial adaptation to the phyllosphere. Following the identification of genes that are up-regulated during phyllosphere colonization, the response regulator PhyR (phyllosphere-induced regulator) was discovered to be crucial for colonization by Methylobacterium spp. ${ }^{61}$ and later also shown to be important for the plant epiphyte Sphingomonas sp. Fr $1^{107}$. PhyR regulates a number of genes typically associated with stress responses, such as heat-shock proteins, the osmo-protectant trehalose, and proteins involved in carotenoid biosynthesis. The response regulator is part of the PhyR-Nep- $\sigma^{\text {EcfG }}$ signaling cascade, which governs the general stress response in Alphaproteobacteria ${ }^{108}$. As stressful conditions in environmental settings are the rule rather than the exception, it will be interesting to determine the degree to which such global systems constitute "alternative" regulatory systems, as is commonly assumed. In contrast to the Alphaproteobacteria, analysis of two gammaproteobacterial Pseudomonas fluorescens strains showed that sigma factor $\sigma^{\mathrm{S}}$, which governs general stress response in these bacteria, seems to play only a minor role in epiphytic fitness ${ }^{109}$. This finding argues against an oversimplification of common stress-response models, as highly environmentally resistant strains may use multiple, redundant regulatory mechanisms to ensure survival.

In P. syringae, another sigma factor belonging to the ECF family, $\operatorname{AlgT}\left(\mathrm{AlgU}, \mathrm{RpoE}\right.$, or $\sigma^{22}$ ), is important for in planta fitness ${ }^{64,110}$. However, the regulatory phenotypes have not yet been causally connected to fitness in terms of surviving desiccation and osmotic stress. Obviously, the analysis of the regulons controlled by these factors will help to further dissect the significance of individual traits. Beyond sigma-factor regulation, other global regulatory systems, including the GasSR two-component system in pseudomonads, have been uncovered.

Another layer of complexity in these regulatory networks lies in second-messenger molecules such as cyclic-di-GMP, which is often involved in controlling different traits including adhesion ${ }^{111}$. The production of these molecules is regulated by various inputs as has been demonstrated for X. campestris $^{112}$. Although insights into the importance of the secondary metabolites of Pseudomonas isolates in the rhizosphere are emerging ${ }^{113}$, systematic analyses of the importance of cyclic-di-GMP signaling in most epiphytic bacteria are currently lacking. 
Last but not least, quorum sensing has been established as an important regulatory system in plant-pathogenic bacteria ${ }^{114}$, for example during the epiphytic phase, which proceeds the endophytic pathogenic lifestyle, in Pseudomonas spp. ${ }^{115,116}$. Quorum sensing represents a means by which bacteria process information on cell density and/or diffusion ${ }^{114,117}$. This system depends on acyl homoserine lactones as signals in Pseudomonas ${ }^{114}$ and Methylobacterium spp. ${ }^{118}$ as well as on the diffusible signal factor DSF in Xanthomonas spp. ${ }^{119}$. Further details on quorum sensing in P. syringae B728, which is the best-studied strain with respect to the importance of this regulatory system for epiphytic growth are given in Box 1.

\section{Interactions with the host and among microbial community members}

Complex interactions are expected to exist in the phyllosphere between various microorganisms, including bacteria and fungi, as well as between microorganisms and host plants (Fig. 4), and even among microorganisms and higher eukaryotes ${ }^{120}$. The relationships between microorganisms and their hosts include parasitic, commensal, and mutualistic interactions. A clear classification can bedifficult, particularly discriminating between commensals and mutualistic symbionts, and it has been suggested that these interactions represent a continuum ${ }^{121,122}$. In the human gut, many community members that were once considered commensals are now regarded as beneficial symbionts because of their contributions to host metabolism and immunity ${ }^{123}$. The thought-provoking statement by Janzen, "Plants wear their guts on the outside"124 suggests that similar questions on host benefit and microbemicrobe interactions should be applied to phyllosphere communities. For phyllosphere microorganisms, the benefits provided by the plant are obvious and include nutrient supply but the advantages provided by phyllosphere inhabitants to their host plants are not necessarily as apparent. It has been suggested that plants benefit from microbial production of plant hormones, such as cytokinins and IAA; however, studies carefully analysing the effects of defects in these traits are not yet available. While the reactions of the plant to leaf pathogens have been studied on the transcriptional level, the responses to "commensal" phyllosphere bacteria remain poorly characterized; however preliminary analysis indicates that plants respond to the presence of a non-pathogenic Pseudomonas strain ${ }^{125}$. Research on induced systemic resistance (ISR), a mechanism that provides 
resistance to a wide range of pathogens and is induced by beneficial microorganisms in the rhizosphere, is not yet well established for phyllosphere bacteria. Likewise, functional studies that might uncover the potential of microorganisms to assist in plant defense, e.g. through the production of secondary toxic metabolites or scavenging of essential macroelements as observed in the rhizosphere ${ }^{49,126}$, are yet to be done in the phyllosphere.

The term "barrier effect" was coined ${ }^{127}$ to describe the resistance to infection by pathogens that is conferred by the human gut microbiota. Indigenous microbial populations may also affect the outcome of plant-pathogen interactions in the phyllosphere ${ }^{11,128}$. As a consequence, it is not surprising that axenic plants are more susceptible to infection, by analogy to animal model systems ${ }^{34}$. In general, the interactions that prevail in planta are far from being understood, and it will be important to attain more system-level insights into the complex interactions that govern outcomes among community members in the context of the plant host. The use of gnotobiotic conditions will be crucial to address the importance of indigenous bacteria and to study microbial interactions in the phyllosphere. Recently, the potential of Sphingomonas isolates in plant protection against bacterial pathogens in a three species Arabidopsis model system has been demonstrated ${ }^{34}$. Although the molecular basis for reduced pathogen growth in the presence of Sphingomonas is not yet understood, evidence is available to suggest that several traits might contribute to the outcome of plant protection ${ }^{129}$.

The traits important for successful epiphytic growth, which were discussed in the previous section, link directly to interactions with other community members; these traits will ultimately allow coexistence or exclusion of other phyllosphere bacteria (see also ${ }^{130}$ ). In microbial communities, competition for space and nutrient resources as well as the production of antibiotics and interference with cell signaling systems are considered to be the principal mechanisms by which indigenous bacteria and fungi antagonize each other ${ }^{3,96,131}$. These traits all appear important and have been shown to be significant in correlational studies; however, experimental proof on the molecular level is lacking or has failed to support previously hypothesized traits. Although antibiosis is the most commonly studied mechanism, it is well known that in vitro antibiosis is not necessarily predictive of in planta antibiosis ${ }^{95,128}$. At present, the factors that determine interactions between epiphytic microorganisms and that ultimately shape microbial communities are poorly elucidated. 


\section{Applications for phyllosphere microbiology}

A prominent area of applied phyllosphere microbiology is the improvement of plant health to increase plant biomass production and prevent biomass losses. As mentioned above, many foliar bacterial pathogens colonize plant surfaces prior to infection, and the size of these populations is correlated with disease severity $34,132,133$. This suggests that a reduction in pathogen numbers could lead to plant protection. Possible mechanisms to suppress pathogen proliferation include exploiting competition for nutrients and space, antibiosis, and stimulating systemic host responses ${ }^{128,134}$. Alternative biocontrol strategies that have been proposed use individual protective strains or strain combinations, see e.g. ${ }^{135,136}$. For a recent review on plant protection in the rhizosphere and phyllosphere see Ref. ${ }^{137}$. A better understanding of the principal drivers of community structure and multitrophic interactions in the phyllosphere will be the key to developing new strategies for plant protection. Biocontrol applications will benefit from fundamental research; in other words, the better we understand the roles and importance of indigenous bacteria, the better we will be able to predict and protect against pathogen infection. Other aspects of applied phyllosphere microbiology relate to the occurrence of human pathogenic bacteria in food including fruits, vegetables and salads. This area of research has been stimulated in the past years by numerous outbreaks of infection associated with foodborne pathogens such as Salmonella and Escherichia coli and advances in the research area have been reviewed recently ${ }^{138}$. Another intriguing area of interest is phytoremediation, using the phyllosphere microorganisms to remove gaseous pollutants such as phenol or benzene from the air (“phylloremediation") $)^{139,140}$.

\section{Conclusions}

The phyllosphere was once termed a neglected milieu ${ }^{1}$. This situation has changed, and there is now an increased interest in phyllosphere microbiology. The phyllosphere is an well-suited model system in which to study basic principles of ecology in particular due its amenability to experimentation and visual inspection, ${ }^{141}$ and this area of research field has the potential to have an impacts on diverse areas such as plant health and atmospheric chemistry. There is still a major focus on understanding 
pathogen/plant interactions; however, there is growing awareness of the importance of the indigenous microbiota and their role in microbe-microbe and host-microbe interactions. There have been substantial advancements in identifying community members and epiphytic fitness traits. New approaches that would not have been possible a few years ago, such as community profiling based on next generation sequencing technologies as well as proteogenomics or metaproteogenomics, help to understand how microbial communities are shaped and to identify new targets for hypothesis-driven research with the aim of uncovering novel protein functions of importance for survival and growth in the phyllosphere. There is a great need to study phyllosphere microorganisms and their interactions in situ and at the microscale using complementary approaches.

Many important questions are still unanswered. What are the drivers of microbial community structure in the phyllosphere? Are there epistatic effects? How stable or easily disturbed are microbial communities? How do closely related microbial genotypes coexist in the phyllosphere? What are the impacts of microorganisms on the host plant? Future research directed at answering these questions will improve our understanding of microbial inhabitants of the phyllosphere and the potential for biotechnological applications. These research efforts should ideally lead to an increase of the availability of genome sequences for representative model strains throughout all phylogenetic taxa detected in the phyllosphere. Such strains will allow the design of synthetic communities and enable a union of genetics studies to obtain direct experimental proof for interactions and to link observations that have been and will be made under environmental conditions with those that can be traced to the molecular level.

\section{Glossary}

\section{Perennial plants}

Plants that lives for more than two years

\section{Deciduous plants}


Plants that lose their leaves seasonally

\section{Evergreen plants}

[au; please define]

\section{Epiphytes}

\section{AU: please define}

Oligotrophic

AU: please define

\section{Stomata}

Openings of leaves that control gas exchange (in particular oxygen and carbon dioxide) and water transpiration between the plant interior and the environment.

\section{Trichomes}

Epidermal outgrowth of plant surfaces including the leaves. A common type is a hair which might be branched or unbranched. Glandular trichomes excrete various exudates.

Hydathodes

\section{AU: please define}

\section{Apoplast}

Au: please define

\section{Coronatine}

Phytotoxin produced by several pathovars of Pseudomonas syringae. It consists of coronafacic acid (CFA), an analog of methyl jasmonic acid (MeJA), and coronamic acid (CMA), which resembles 1- 
aminocyclopropane-1-carboxylic acid (ACC), a precursor to ethylene. Has been shown to open stomata.

\section{Syringolin A}

Major variant of a family of structurally related small cyclic peptides that are secreted by many phytopathogenic bacterial strains. Syringolin A counteracts stomatal closure by proteasome inhibition.

\section{Photolyase}

Enzyme involved in DNA repair caused by UV light. This flavoprotein reversibly binds to pyrimidine dimers and converts them back to the original base, a reaction for which visible light is required.

\section{Trehalose}

Disaccharide of two glucose units, formed by an $\alpha, \alpha-1,1$-glucoside bond. Important for dessciation resistance.

\section{Microbial associated molecular pattern (MAMP)}

Molecular component characteristic for microorganisms; their recognition plays a key role in innate immunity.

\section{Bacteriorhodopsins}

Retinal-containing transmembrane proteins that act as light-driven proton pumps.

\section{$\underline{\text { hrp genes }}$}

Encode for proteins that constitute the type III secretion system of phytopathogenic bacteria, which is used to transport effectors into plant cells and elicit a hypersensitive response when recognized by resistance proteins.

\section{Axenic}


Culture of an organism, here a plant, that is free of contaminating organisms.

\section{Antibiosis}

Biological interaction between two species whereby one acts antagonistic to the other one by producing a substance that inhibits growth of the latter or kills it.

\section{Acknowledgements.}

Work in the author's laboratory is supported by research grants from the Swiss National Foundation (SNSF), ETH Zurich, the Vontobel Foundation, the Swiss Agency of Innovation in Technology (KTI/CTI), the Swiss Initiative for Systems Biology SystemsX, the European Science Foundation (ESF), and the European Union (FP7). Claudia Knief, Mitja Remus-Emsermann and Natacha Bodenhausen are greatly acknowledged for comments on the manuscript. I like to thank the anonymous reviewers for helpful suggestions that improved this review. I am grateful to G. Innerebner and M. Remus-Emsermann for providing pictures for Figure 1 and to Manuel Stark and Christian von Mering for preparing Figure 2. 
Table 1. Major bacterial genera detected in phyllosphere samples.

Asking au to rethink presentation

\begin{tabular}{|c|c|c|c|c|c|c|}
\hline Class & Order & Genus & A. thaliana & Soybean & Clover & Rice \\
\hline \multirow{17}{*}{ Alphaproteobacteria } & Rhizobiales & Agrobacterium & It & [ & I & \\
\hline & Rhizobiales & Bradyrhizobium & I & $\overline{0}$ & 7 & \\
\hline & Rhizobiales & Brucella & & I & i & I \\
\hline & Caulobacterales & Caulobacter & tir & I & a & \\
\hline & Sphingomonadales & Erythrobacter & 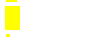 & & $\square$ & \\
\hline & Rhodospirillales & Magnetospirillum & & I & I & I \\
\hline & $\begin{array}{l}\text { Rhizobiales } \\
\text { la }\end{array}$ & Mesorhizobium & & $\mathbf{i}$ & i & \\
\hline & Rhizobiales & Methylobacterium & a & & & \\
\hline & Sphingomonadales & Novosphingobium & F & $\overline{7}$ & $\bar{\square}$ & \\
\hline & Rhizobiales & Ochrobactrum & & I & & प \\
\hline & Rhizobiales & Rhizobium & a & $\square$ & 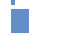 & Z \\
\hline & Rhizobiales & Rhodopseudomonas & I & E & $\overline{1}$ & \\
\hline & Rhizobiales & Sinorhizobium & [1] & $\bar{E}$ & $\overline{\mathbf{I}}$ & i \\
\hline & Sphingomonadales & Sphingobium & I & $\mathbf{\square}$ & $\square$ & \\
\hline & Sphingomonadales & Sphingomonas & 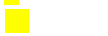 & 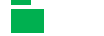 & D & i \\
\hline & Sphingomonadales & Sphingopyxis & 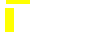 & $\mathbf{\square}$ & $\square$ & i \\
\hline & Sphingomonadales & Zymomonas & I & I & I & \\
\hline \multirow[t]{3}{*}{ Betaproteobacteria } & Burkholderiales & Acidovorax & $\|$ & 】 & I & | \\
\hline & Burkholderiales & Burkholderia & 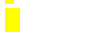 & 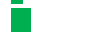 & 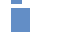 & 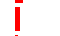 \\
\hline & Burkholderiales & Variovorax & I & I & I & i \\
\hline \multirow[t]{6}{*}{ Gammaproteobacteria } & Pseudomonadales & Acinetobacter & & & | & 】 \\
\hline & Enterobacteriales & Enterobacter & & & & \\
\hline & Enterobacteriales & Pantoea & & I & I & 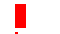 \\
\hline & Pseudomonadales & Pseudomonas & 口 & & 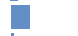 & \\
\hline & Xanthomonadales & Stenotrophomonas & & & & ] \\
\hline & Xanthomonadales & Xanthomonas & I & 【 & 】 & I \\
\hline \multirow[t]{9}{*}{ Actinobacteria } & Actinomycetales & Aeromicrobium & & & & I \\
\hline & Actinomycetales & Arthrobacter & I & I & 1 & \\
\hline & Actinomycetales & Clavibacter & 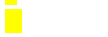 & i & i & \\
\hline & Actinomycetales & Leifsonia & 1 & & & \\
\hline & Actinomycetales & Mycobacterium & [ & I & I & \\
\hline & Actinomycetales & Nakamurella & & & & \\
\hline & Actinomycetales & Nocardioides & & & & ] \\
\hline & Acinomycetales & Streptomyces & 四 & I & 1 & 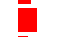 \\
\hline & Actinomycetales & Rhodococcus & ॥ & $\overline{\mathbf{I}}$ & Î & I \\
\hline \multirow{7}{*}{ Bacteriodetes } & Bacteroidales & Bacteroides & [ & I & I & \\
\hline & Sphingobacteriales & Chitinophaga & I & i & & \\
\hline & Cytophagales & Cytophaga & 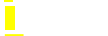 & i & 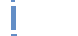 & \\
\hline & Cytophagales & Dyadobacter & 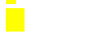 & i & i & \\
\hline & Flavobacteriales & Flavobacterium & II & 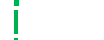 & i & \\
\hline & Sphingobacteriales & Pedobacter & 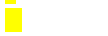 & i & i & \\
\hline & Cytophagales & Spirosoma & $\square$ & i & 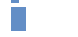 & I \\
\hline
\end{tabular}

The length of the bars represents the relative frequency of reads with predicted proteins and ribosomal RNA genes annotated to the genus level within the metagenomes of microbial communities ${ }^{12,19}$ using the MG-Rast (metagenomics.anl.gov/). A threshold of greater than $1 \%$ of the overall community was set. 
Table 2. Global approaches applied to phyllosphere bacteria to uncover epiphytic fitness traits under in situ conditions.

\begin{tabular}{|c|c|c|c|}
\hline Approach & Biological system & Major findings & Ref. \\
\hline Transposon mutagenesis & $\begin{array}{l}\text { P. syringae pv. syringae } \\
\text { B728a - bean phyllosphere }\end{array}$ & $\begin{array}{l}\text { Various traits contribute incrementally to epiphytic } \\
\text { fitness; identified traits concern motility and stress } \\
\text { tolerance }\end{array}$ & 54 \\
\hline \multirow[t]{4}{*}{ Promoter trapping } & $\begin{array}{l}\text { P. syringae pv. tomato } \\
\text { DC } 3000 \text { - A. thaliana }\end{array}$ & $\begin{array}{l}\text { Identification of virulence genes, genes for proteins } \\
\text { involved in stress tolerance, polysaccharide synthesis, } \\
\text { transport and carbon metabolism, unknown loci }\end{array}$ & 142 \\
\hline & $\begin{array}{l}\text { P. syringae pv. syringae } \\
\text { B728a - bean phyllosphere }\end{array}$ & $\begin{array}{l}\text { Identification of virulence genes, genes for proteins } \\
\text { involved in regulation, stress tolerance, } \\
\text { polysaccharide synthesis, transport and carbon } \\
\text { metabolism, unknown loci }\end{array}$ & 101 \\
\hline & $\begin{array}{l}X . \text { campestris pv. vesicatoria }- \\
\text { tomato }\end{array}$ & $\begin{array}{l}\text { Identification of a citrate transporter, which was } \\
\text { shown to be required for virulence }\end{array}$ & 143 \\
\hline & $\begin{array}{l}\text { D. dadantii (E. chrysanthemi } \\
\text { 3937) }\end{array}$ & $\begin{array}{l}\text { Identification of genes for proteins involved in } \\
\text { metabolism, regulation, transport, unknown loci }\end{array}$ & 144 \\
\hline Transcriptomics & $\begin{array}{l}\text { D. dadantii (E. chrysanthemi } \\
\text { 3937) }\end{array}$ & $\begin{array}{l}\text { Identification of virulence genes, genes for proteins } \\
\text { involved in iron uptake, transport, xenobiotic } \\
\text { resistance, chemotaxis, stress responses }\end{array}$ & 145 \\
\hline Proteomics & M. extorquens AM1 & $\begin{array}{l}\text { Up-regulation of stress proteins and enzymes involved } \\
\text { in methylotrophy; discovery of PhyR (general stress } \\
\text { response regulator of Alphaproteobacteria) }\end{array}$ & 61 \\
\hline Metaproteogenomics & $\begin{array}{l}\text { Microbial community - } \\
\text { Soybean, clover, } A \text {. thaliana }\end{array}$ & $\begin{array}{l}\text { Common repertoire of proteins expressed by bacterial } \\
\text { communities on different plants }\end{array}$ & 12 \\
\hline Metaproteogenomics & $\begin{array}{l}\text { Microbial community - } \\
\text { rice }\end{array}$ & Large set of proteins related to one carbon metabolism & 19 \\
\hline
\end{tabular}


[fig legs may (will) change]

Figure 1. The phyllosphere environment.

Electron micrograph pictures showing the edge of a leaf (a), and epiphytic bacteria that become visual after higher magnification (b). Schematic view of a leaf surface and the apoplastic space (c). Epifluorescence pictures of tagged phyllosphere bacteria $(P$. agglomerans strain $299 \mathrm{R}$ in cyan and $P$. syringae DC3000 in red) (d).

Figure 2. Microbial phyllosphere diversity.

An ML-TreeMap analysis ${ }^{30}$ was performed to assess the microbial community composition in the phyllosphere of A. thaliana (yellow), soybean (green), clover (blue), and rice (red) from samples obtained after shotgun metagenome sequencing of assembled and unassembled reads as described in Delmotte et al. $2009^{12}$ and Knief et al. $2012^{19}$ (publically available through the MG-RAST server). The backbone tree was calculated based on aligned sequences of 40 phylogenetic marker genes from fully sequenced organisms. Dots indicate the placement of metagenomic sequence reads containing these marker genes, with the size of the dot corresponding to the frequency of recovery. Archaea (green part of inner cycle) contributed less than $1 \%$ to the microbial community of the samples. Note, the low contribution of eukaryotes (red part of inner cycle) is in accordance with the design of the microbial harvesting procedure, which included a physical depletion step for eukaryotic cells.

Figure 3. Proposed bacterial traits involved in adaptation to the phyllosphere acting either at the community level, with the plant or the level of the individual cell.

Figure 4. Multipartite interactions occurring in the phyllosphere among commensal and pathogenic microorganisms as well as the plant. 


\section{Box 1. Quorum sensing in Pseudomonas syringae.}

Many Gram-negative plant associated bacteria including Pseudomonas syringae produce acyl homoserine lactones (acyl-HSL) as quorum sensing signal molecules. One of the best studied phyllosphere bacteria regarding the importance of HSLs is Pseudomonas syringae pv. syringae B728a. It has been shown that AhlI, which is the synthase responsible for 3-oxo-hexanoyl HSL production, is under the control of AhlR and other regulators. Quorum sensing in P. syringae B728a is important for epiphytic fitness by inducing EPS production and indirectly desiccation and resistance to hydrogen peroxide, as well as suppressing motility ${ }^{115,116}$. In addition, it has been shown that $P$. syringae acylHSL-dependent signalling in the phyllosphere was strongly influenced both by the size of cell aggregates and by the availability of water on leaves ${ }^{146}$. EPS production by acyl-HSL was thus postulated to increase the survival of epiphytes under desiccating conditions where acyl-HSL accumulates faster. On the other hand, motility, which is negatively regulated acyl-HSL-signaling, might reflect an adaptation to dry conditions that would allow the bacterium to conserve the resources invested in flagella when movement is impossible or disadvantageous.

Quorum sensing signaling mechanisms have in common that they principally allow cross talk and are prone to signal quenching. Both phenomena have recently begun to be studied in the phyllosphere, and may be relevant and contribute to the complex interaction of microorganisms in this niche [au: ok? $]^{147-150}$. 
Ruinen, J. Occurrence of Beijerinckia species in the phyllosphere. Nature 177, 220-221 (1956).

2 Woodward, F. I. \& Lomas, M. R. Vegetation dynamics - simulating responses to climatic change. Biol Rev 79, 643-670 (2004).

3 Lindow, S. E. \& Brandl, M. T. Microbiology of the phyllosphere. Appl Environ Microb 69, 1875-1883 (2003).

4 Baldotto, L. E. B. \& Olivares, F. L. Phylloepiphytic interaction between bacteria and different plant species in a tropical agricultural system. Can J Microbiol 54, 918-931 (2008).

5 Leveau, J. H. J. \& Lindow, S. E. Appetite of an epiphyte: Quantitative monitoring of bacterial sugar consumption in the phyllosphere. Proc Natl Acad Sci USA 98, 3446-3453 (2001).

6 Miller, W. G., Brandl, M. T., Quinones, B. \& Lindow, S. E. Biological sensor for sucrose availability: Relative sensitivities of various reporter genes. Appl Environ Microb 67, 13081317 (2001).

7 Remus-Emsermann, M. N., Tecon, R., Kowalchuk, G. A. \& Leveau, J. H. Variation in local carrying capacity and the individual fate of bacterial colonizers in the phyllosphere. Isme J 6, 756-765 (2012).

8 Boller, T. \& Felix, G. A renaissance of elicitors: Perception of microbe-associated molecular patterns and danger signals by pattern-recognition receptors. Annu Rev Plant Biol 60, 379406 (2009).

9 Hirano, S. S. \& Upper, C. D. Bacteria in the leaf ecosystem with emphasis on Pseudomonas syringae - a pathogen, ice nucleus, and epiphyte. Microbiol Mol Biol R 64, 624-653 (2000).

10 Wilson, M., Hirano, S. S. \& Lindow, S. E. Location and survival of leaf-associated bacteria in relation to pathogenicity and potential for growth within the leaf. Appl Environ Microb 65, 1435-1443 (1999).

11 Beattie, G. A. \& Lindow, S. E. The secret life of foliar bacterial pathogens on leaves. Annu Rev Phytopathol 33, 145-172 (1995).

12 Delmotte, N. et al. Community proteogenomics reveals insights into the physiology of phyllosphere bacteria. Proc Natl Acad Sci USA 106, 16428-16433 (2009).

13 Whipps, J. M., Hand, P., Pink, D. \& Bending, G. D. Phyllosphere microbiology with special reference to diversity and plant genotype. J Appl Microbiol 105, 1744-1755 (2008).

14 Redford, A. J. \& Fierer, N. Bacterial succession on the leaf surface: A novel system for studying successional dynamics. Microb Ecol 58, 189-198 (2009).

15 Yang, C. H., Crowley, D. E., Borneman, J. \& Keen, N. T. Microbial phyllosphere populations are more complex than previously realized. P Natl Acad Sci USA 98, 3889-3894 (2001).

16 Jumpponen, A. \& Jones, K. L. Massively parallel 454 sequencing indicates hyperdiverse fungal communities in temperate Quercus macrocarpa phyllosphere. New Phytol 184, 438448 (2009).

17 Finkel, O. M., Burch, A. Y., Lindow, S. E., Post, A. F. \& Belkin, S. Geographical location determines the population structure in phyllosphere microbial communities of a saltexcreting desert tree. Appl Environ Microb 77, 7647-7655 (2011).

18 Kim, M. et al. Distinctive phyllosphere bacterial communities in tropical trees. Microb Ecol 63, 674-681 (2012).

19 Knief, C. D., N; Chaffron, S.; Stark, M., Innerebner, G.; Wassmann, R.; von Mering, C.; Vorholt, J.A. Metaproteogenomic analysis of microbial communities in the phyllosphere and rhizosphere of rice. ISME J. 6, 1378-1390 (2012). 
Andrews, J. H., Spear, R. N. \& Nordheim, E. V. Population biology of Aureobasidium pullulans on apple leaf surfaces. Can J Microbiol 48, 500-513 (2002).

21 Morris, C. E., Monier, J. M. \& Jacques, M. A. A technique to quantify the population size and composition of the biofilm component in communities of bacteria in the phyllosphere. Appl Environ Microb 64, 4789-4795 (1998).

Monier, J. M. \& Lindow, S. E. Frequency, size, and localization of bacterial aggregates on bean leaf surfaces. Appl Environ Microb 70, 346-355 (2004).

23 Tecon, R. \& Leveau, J. H. The mechanics of bacterial cluster formation on plant leaf surfaces as revealed by bioreporter technology. Environ. Microbiol. 14, 1325-1332 (2012).

Perez-Velazquez, J. et al. Stochastic modeling of Pseudomonas syringae growth in the phyllosphere. Math Biosci 239, 106-116 (2012).

Monier, J. M. \& Lindow, S. E. Spatial organization of dual-species bacterial aggregates on leaf surfaces. Appl Environ Microb 71, 5484-5493 (2005).

Rastogi, G. et al. Leaf microbiota in an agroecosystem: spatiotemporal variation in bacterial community composition on field-grown lettuce. ISME J. (2012).

Arnold, A. E. \& Lutzoni, F. Diversity and host range of foliar fungal endophytes: are tropical leaves biodiversity hotspots? Ecology 88, 541-549 (2007).

Lambais, M. R., Crowley, D. E., Cury, J. C., Bull, R. C. \& Rodrigues, R. R. Bacterial diversity in tree canopies of the Atlantic forest. Science 312, 1917 (2006).

von Mering, C. et al. Quantitative phylogenetic assessment of microbial communities in diverse environments. Science 315, 1126-1130 (2007).

Stark, M., Berger, S. A., Stamatakis, A. \& von Mering, C. MLTreeMap - accurate Maximum Likelihood placement of environmental DNA sequences into taxonomic and functional reference phylogenies. BMC Genomics 11, 461 (2010).

31 Beattie, G. A. \& Marcell, L. M. Comparative dynamics of adherent and nonadherent bacterial populations on maize leaves. Phytopathology 92, 1015-1023 (2002).

32 Knief, C., Frances, L. \& Vorholt, J. A. Competitiveness of diverse Methylobacterium strains in the phyllosphere of Arabidopsis thaliana and identification of representative models, including M. extorquens PA1. Microb Ecol 60, 440-452 (2010).

33 Feil, H. et al. Comparison of the complete genome sequences of Pseudomonas syringae pv. syringae B728a and pv. tomato DC3000. Proc Natl Acad Sci USA 102, 11064-11069 (2005).

34 Innerebner, G., Knief, C. \& Vorholt, J. A. Protection of Arabidopsis thaliana against leafpathogenic Pseudomonas syringae by Sphingomonas strains in a controlled model system. Appl Environ Microb 77, 3202-3210 (2011).

35 da Silva, A. C. et al. Comparison of the genomes of two Xanthomonas pathogens with differing host specificities. Nature 417, 459-463 (2002).

36 Brandl, M., Clark, E. M. \& Lindow, S. E. Characterization of the indole-3 acetic acid (IAA) biosynthetic pathway in an epiphytic strain of Erwinia herbicola and IAA production in vitro. Can J Microbiol 42, 586-592 (1996).

37 Vanden Wymelenberg, A., Cullen, D., Spear, R. \& Andrews, J. Regulated expression of green fluorescent protein under the control of Aureobasidium pullulans xylanase gene xynA. Fems Microbiol Lett 181, 205-209 (1999).

38 Knief, C., Ramette, A., Frances, L., Alonso-Blanco, C. \& Vorholt, J. A. Site and plant species are important determinants of the Methylobacterium community composition in the plant phyllosphere. Isme J 4, 719-728 (2010).

39 Kadivar, H. \& Stapleton, A. E. Ultraviolet radiation alters maize phyllosphere bacterial diversity. Microb Ecol 45, 353-361 (2003).

40 Yutthammo, C., Thongthammachat, N., Pinphanichakarn, P. \& Luepromchai, E. Diversity and activity of PAH-degrading bacteria in the phyllosphere of ornamental plants. Microb Ecol 59, 357-368 (2010).

41 Suda, W., Nagasaki, A. \& Shishido, M. Powdery Mildew-infection changes bacterial community composition in the phyllosphere. Microbes Environ 24, 217-223 (2009). 
42 Ikeda, S. et al. Autoregulation of nodulation interferes with impacts of nitrogen fertilization levels on the leaf-associated bacterial community in soybeans. Appl Environ Microb 77, 1973-1980 (2011).

43 Zimmerman, N. B. \& Vitousek, P. M. Fungal endophyte communities reflect environmental structuring across a Hawaiian landscape. Proc Natl Acad Sci U S A 109, 13022-13027 (2012).

44 Jumpponen, A. \& Jones, K. L. Seasonally dynamic fungal communities in the Quercus macrocarpa phyllosphere differ between urban and nonurban environments. New Phytol 186, 496-513 (2010).

45 Redford, A. J., Bowers, R. M., Knight, R., Linhart, Y. \& Fierer, N. The ecology of the phyllosphere: geographic and phylogenetic variability in the distribution of bacteria on tree leaves. Environ Microbiol 12, 2885-2893 (2010).

46 Hunter, P. J., Hand, P., Pink, D., Whipps, J. M. \& Bending, G. D. Both leaf properties and microbe-microbe interactions influence within-species variation in bacterial population diversity and structure in the lettuce (Lactuca species) phyllosphere. Appl Environ Microb 76, 8117-8125 (2010).

47 Kniskern, J. M., Traw, M. B. \& Bergelson, J. Salicylic acid and jasmonic acid signaling defense pathways reduce natural bacterial diversity on Arabidopsis thaliana. Mol Plant Microbe Interact 20, 1512-1522 (2007).

48 Balint-Kurti, P., Simmons, S. J., Blum, J. E., Ballare, C. L. \& Stapleton, A. E. Maize leaf epiphytic bacteria diversity patterns are genetically correlated with resistance to fungal pathogen infection. Mol Plant Microbe Interact 23, 473-484 (2010).

49 Cook, R. J. et al. Molecular mechanisms of defense by Rhizobacteria against root disease. Proc Natl Acad Sci USA 92, 4197-4201 (1995).

50 Mendes, R. et al. Deciphering the rhizosphere microbiome for disease-suppressive bacteria. Science 332, 1097-1100 (2011).

51 Bulgarelli, D. et al. Revealing structure and assembly cues for Arabidopsis root-inhabiting bacterial microbiota. Nature 488, 91-95 (2012).

52 Lundberg, D. S. et al. Defining the core Arabidopsis thaliana root microbiome. Nature 488, 86-90 (2012).

53 Darrasse, A. et al. Transmission of plant-pathogenic bacteria by nonhost seeds without induction of an associated defense reaction at emergence. Appl Environ Microb 76, 67876796 (2010).

54 Lindow, S. E., Andersen, G. \& Beattie, G. A. Characteristics of insertional Mmtants of Pseudomonas syringae with reduced epiphytic fitness. Appl Environ Microb 59, 1593-1601 (1993).

55 Wichmann, G. \& Bergelson, J. Effector genes of Xanthomonas axonopodis pv. vesicatoria promote transmission and enhance other fitness traits in the field. Genetics 166, 693-706 (2004).

56 Lee, J. et al. Type III secretion and effectors shape the survival and growth pattern of Pseudomonas syringae on leaf surfaces. Plant Physiol 158, 1803-1818 (2012).

57 Melotto, M., Underwood, W., Koczan, J., Nomura, K. \& He, S. Y. Plant stomata function in innate immunity against bacterial invasion. Cell 126, 969-980 (2006).

58 Schellenberg, B., Ramel, C. \& Dudler, R. Pseudomonas syringae virulence factor Syringolin A counteracts stomatal immunity by proteasome inhibition. Mol Plant Microbe In 23, 12871293 (2010).

59 Jacobs, J. L., Carroll, T. L. \& Sundin, G. W. The role of pigmentation, ultraviolet radiation tolerance, and leaf colonization strategies in the epiphytic survival of phyllosphere bacteria. Microb Ecol 49, 104-113 (2005).

60 Gunasekera, T. S. \& Sundin, G. W. Role of nucleotide excision repair and photoreactivation in the solar UVB radiation survival of Pseudomonas syringae pv. syringae B728a. J Appl Microbiol 100, 1073-1083 (2006). 
61 Gourion, B., Rossignol, M. \& Vorholt, J. A. A proteomic study of Methylobacterium extorquens reveals a response regulator essential for epiphytic growth. Proc Natl Acad Sci USA 103, 13186-13191 (2006).

62 Beattie, G. A. Water relations in the interaction of foliar bacterial pathogens with plants. Annual Review of Phytopathology 49, 533-555 (2011).

63 Monier, J. M. \& Lindow, S. E. Differential survival of solitary and aggregated bacterial cells promotes aggregate formation on leaf surfaces. Proc Natl Acad Sci USA 100, 15977-15982 (2003).

64 Yu, J., Penaloza-Vazquez, A., Chakrabarty, A. M. \& Bender, C. L. Involvement of the exopolysaccharide alginate in the virulence and epiphytic fitness of Pseudomonas syringae pv. syringae. Mol Microbiol 33, 712-720 (1999).

65 Chang, W. S. et al. Alginate production by Pseudomonas putida creates a hydrated microenvironment and contributes to biofilm architecture and stress tolerance under water-limiting conditions. J Bacteriol 189, 8290-8299 (2007).

66 Rigano, L. A. et al. Biofilm formation, epiphytic fitness, and canker development in Xanthomonas axonopodis pv citri. Mol Plant Microbe In 20, 1222-1230 (2007).

67 Bunster, L., Fokkema, N. J. \& Schippers, B. Effect of surface-active Pseudomonas spp on leaf wettability. Appl Environ Microb 55, 1340-1345 (1989).

68 Schreiber, L. et al. Plant-microbe interactions: identification of epiphytic bacteria and their ability to alter leaf surface permeability. New Phytol 166, 589-594 (2005).

69 Axtell, C. A. \& Beattie, G. A. Construction and characterization of a proU-gfp transcriptional fusion that measures water availability in a microbial habitat. Appl Environ Microb 68, 4604-4612 (2002).

70 Chen, C. \& Beattie, G. A. Pseudomonas syringae BetT is a low-affinity choline transporter that is responsible for superior osmoprotection by choline over glycine betaine. $J$ Bacteriol 190, 2717-2725 (2008).

71 Freeman, B. C., Chen, C. L. \& Beattie, G. A. Identification of the trehalose biosynthetic loci of Pseudomonas syringae and their contribution to fitness in the phyllosphere. Environ Microbiol 12, 1486-1497 (2010).

72 Wink, M. Evolution of secondary metabolites from an ecological and molecular phylogenetic perspective. Phytochemistry 64, 3-19 (2003).

73 Giddens, S. R., Houliston, G. J. \& Mahanty, H. K. The influence of antibiotic production and pre-emptive colonization on the population dynamics of Pantoea agglomerans (Erwinia herbicola) Eh1087 and Erwinia amylovora in planta. Environ Microbiol 5, 1016-1021 (2003).

74 Stoitsova, S. O., Braun, Y., Ullrich, M. S. \& Weingart, H. Characterization of the RND-type multidrug efflux pump MexAB-OprM of the plant pathogen Pseudomonas syringae. Appl Environ Microb 74, 3387-3393 (2008).

75 Fan, J. et al. Pseudomonas sax genes overcome aliphatic isothiocyanate-mediated non-host resistance in Arabidopsis. Science 331, 1185-1188 (2011).

76 Haefele, D. M. \& Lindow, S. E. Flagellar motility confers epiphytic fitness advantages upon Pseudomonas syringae. Appl Environ Microb 53, 2528-2533 (1987).

77 Rojas, C. M., Ham, J. H., Deng, W. L., Doyle, J. J. \& Collmer, A. HecA, a member of a class of adhesins produced by diverse pathogenic bacteria, contributes to the attachment,, aggregation, epidermal cell killing, and virulence phenotypes of Erwinia chrysanthemi EC16 on Nicotiana clevelandii seedlings. Proc Natl Acad Sci USA 99, 13142-13147 (2002).

78 Das, A., Rangaraj, N. \& Sonti, R. V. Multiple adhesin-like functions of Xanthomonas oryzae pv. oryzae are involved in promoting leaf attachment, entry, and virulence on rice. Mol Plant Microbe Interact 22, 73-85 (2009).

79 Weibull, J., Ronquist, F. \& Brishammar, S. Free amino-acid-composition of leaf exudates and phloem sap - a comparative-study in oats and barley. Plant Physiol 92, 222-226 (1990). 
Fiala, V., Glad, C., Martin, M., Jolivet, E. \& Derridj, S. Occurrence of soluble carbohydrates on the phylloplane of Maize (Zea mays L) - Variations in relation to leaf heterogeneity and position on the plant. New Phytol 115, 609-615 (1990).

81 Tukey, H. B. Leaching of substances from plants. Ann Rev Plant Physio 21, 305-324 (1970).

82 Remus-Emsermann, M. N. P. \& Leveau, J. H. J. Linking environmental heterogeneity and reproductive success at single-cell resolution. ISME J. 4, 215-222 (2010).

83 Brandl, M. T. \& Lindow, S. E. Contribution of indole-3-acetic acid production to the epiphytic fitness of Erwinia herbicola. Appl Environ Microb 64, 3256-3263 (1998).

84 Limtong, S. \& Koowadjanakul, N. Yeasts from phylloplane and their capability to produce indole-3-acetic acid. World J Microbiol Biotechnol (2012).

85 Fry, S. C. Cellulases, hemicelluloses and auxin-stimulated gorwth: a possible relationship. Physiologia Plantarum 75, 532-536 (1989).

86 Fall, A. \& Benson, A. A. Leaf methanol - the simplest natural product from plants. Trends in Plant Sci. 1, 296-301 (1996).

87 Galbally, I. E. \& Kirstine, W. The production of methanol by flowering plants and the global cycle of methanol. J Atmos Chem 43, 195-229 (2002).

88 Sy, A., Timmers, A. C. J., Knief, C. \& Vorholt, J. A. Methylotrophic metabolism is advantageous for Methylobacterium extorquens during colonization of Medicago truncatula under competitive conditions. Appl Environ Microb 71, 7245-7252 (2005).

89 Kawaguchi, K., Yurimoto, H., Oku, M. \& Sakai, Y. Yeast methylotrophy and autophagy in a methanol-oscillating environment on growing Arabidopsis thaliana leaves. Plos One 6, e25257 (2011).

90 Abanda-Nkpwatt, D., Musch, M., Tschiersch, J., Boettner, M. \& Schwab, W. Molecular interaction between Methylobacterium extorquens and seedlings: growth promotion, methanol consumption, and localization of the methanol emission site. $J$ Exp Bot 57, 40254032 (2006).

91 Wellner, S., Lodders, N. \& Kampfer, P. Diversity and biogeography of selected phyllosphere bacteria with special emphasis on Methylobacterium spp. Syst Appl Microbiol 34, 621-630 (2011).

92 Saito, T. \& Yokouchi, Y. Stable carbon isotope ratio of methyl chloride emitted from glasshouse-grown tropical plants and its implication for the global methyl chloride budget. Geophys. Res. Lett. 35 (2008).

93 Nadalig, T. et al. Detection and isolation of chloromethane-degrading bacteria from the Arabidopsis thaliana phyllosphere, and characterization of chloromethane utilization genes. Fems Microbiol Ecol 77, 438-448 (2011).

94 Keppler, F., Hamilton, J. T. G., Brass, M. \& Rockmann, T. Methane emissions from terrestrial plants under aerobic conditions. Nature 439, 187-191 (2006).

$95 \mathrm{Ji}$, P. S. \& Wilson, M. Assessment of the importance of similarity in carbon source utilization profiles between the biological control agent and the pathogen in biological control of bacterial speck of tomato. Appl Environ Microb 68, 4383-4389 (2002).

96 Wilson, M. \& Lindow, S. E. Coexistence among epiphytic bacterial populations mediated through nutritional resource partitioning. Appl Environ Microb 60, 4468-4477 (1994).

97 Rico, A. \& Preston, G. M. Pseudomonas syringae pv. tomato DC3000 uses constitutive and apoplast-induced nutrient assimilation pathways to catabolize nutrients that are abundant in the tomato apoplast. Mol Plant Microbe Interact 21, 269-282 (2008).

98 Blanvillain, S. et al. Plant carbohydrate scavenging through TonB-dependent receptors: A feature shared by phytopathogenic and aquatic bacteria. Plos One 2, e224 (2007).

99 Papen, H., Gessler, A., Zumbusch, E. \& Rennenberg, H. Chemolithoautotrophic nitrifiers in the phyllosphere of a spruce ecosystem receiving high atmospheric nitrogen input. Curr Microbiol 44, 56-60 (2002). 
100 Furnkranz, M. et al. Nitrogen fixation by phyllosphere bacteria associated with higher plants and their colonizing epiphytes of a tropical lowland rainforest of Costa Rica. Isme J 2, 561-570 (2008).

101 Marco, M. L., Legac, J. \& Lindow, S. E. Pseudomonas syringae genes induced during colonization of leaf surfaces. Environ Microbiol 7, 1379-1391 (2005).

102 Wensing, A. et al. Impact of siderophore production by Pseudomonas syringae pv. syringae 22d/93 on epiphytic fitness and biocontrol activity against Pseudomonas syringae pv. glycinea 1a/96. Appl Environ Microb 76, 2704-2711 (2010).

103 Joyner, D. C. \& Lindow, S. E. Heterogeneity of iron bioavailability on plants assessed with a whole-cell GFP-based bacterial biosensor. Microbiol SGM 146, 2435-2445 (2000).

104 Karamanoli, K., Bouligaraki, P., Constantinidou, H. I. A. \& Lindow, S. E. Polyphenolic compounds on leaves limit iron availability and affect growth of epiphytic bacteria. Ann Appl Biol 159, 99-108 (2011).

105 Atamna-Ismaeel, N. et al. Microbial rhodopsins on leaf surfaces of terrestrial plants. Environ Microbiol 14, 140-146 (2012).

106 Atamna-Ismaeel, N. et al. Bacterial anoxygenic photosynthesis on plant leaf surfaces. Environ. Microbiol. Rep. 4, 209-216 (2012).

107 Kaczmarczyk, A. et al. Role of Sphingomonas sp strain Fr1 PhyR- NepR-sigma(EcfG) cascade in general stress response and identification of a negative regulator of PhyR. $J$ Bacteriol 193, 6629-6638 (2011).

108 Francez-Charlot, A. et al. Sigma factor mimicry involved in regulation of general stress response. Proc Natl Acad Sci USA 106, 3467-3472 (2009).

109 Hagen, M. J., Stockwell, V. O., Whistler, C. A., Johnson, K. B. \& Loper, J. E. Stress tolerance and environmental fitness of Pseudomonas fluorescens A506, which has a mutation in rpoS. Phytopathology 99, 679-688 (2009).

110 Schenk, A., Weingart, H. \& Ullrich, M. S. The alternative sigma factor AlgT, but not alginate synthesis, promotes in planta multiplication of Pseudomonas syringae pv. glycinea. Microbiol SGM 154, 413-421 (2008).

111 Schirmer, T. \& Jenal, U. Structural and mechanistic determinants of c-di-GMP signalling. Nat Rev Microbiol 7, 724-735 (2009).

112 Ryan, R. P. et al. Cyclic di-GMP signalling in the virulence and environmental adaptation of Xanthomonas campestris. Mol Microbiol 63, 429-442 (2007).

113 Newell, P. D., Yoshioka, S., Hvorecny, K. L., Monds, R. D. \& O'Toole, G. A. Systematic analysis of diguanylate cyclases that promote biofilm formation by Pseudomonas fluorescens Pf0-1. J Bacteriol 193, 4685-4698 (2011).

114 Von Bodman, S. B., Bauer, W. D. \& Coplin, D. L. Quorum sensing in plant-pathogenic bacteria. Annual Review of Phytopathology 41, 455-482 (2003).

115 Quinones, B., Dulla, G. \& Lindow, S. E. Quorum sensing regulates exopolysaccharide production, motility, and virulence in Pseudomonas syringae. Mol Plant Microbe In 18, 682-693 (2005).

116 Quinones, B., Pujol, C. J. \& Lindow, S. E. Regulation of AHL production and its contribution to epiphytic fitness in Pseudomonas syringae. Mol Plant Microbe In 17, 521-531 (2004).

117 Redfield, R. J. Is quorum sensing a side effect of diffusion sensing? Trends Microbiol 10, 365-370 (2002).

118 Nieto Penalver, C. G. et al. Methylobacterium extorquens AM1 produces a novel type of acyl-homoserine lactone with a double unsaturated side chain under methylotrophic growth conditions. Febs Lett 580, 561-567 (2006).

119 Ryan, R. P. \& Dow, J. M. Communication with a growing family: diffusible signal factor (DSF) signaling in bacteria. Trends Microbiol 19, 145-152 (2011).

120 Perez, J. L., French, J. V., Summy, K. R., Baines, A. D. \& Little, C. R. Fungal phyllosphere communities are altered by indirect interactions among trophic levels. Microb Ecol 57, 766774 (2009). 
121 Thrall, P. H., Hochberg, M. E., Burdon, J. J. \& Bever, J. D. Coevolution of symbiotic mutualists and parasites in a community context. Trends Ecol Evol 22, 120-126 (2007).

122 Little, A. E. F., Robinson, C. J., Peterson, S. B., Raffa, K. E. \& Handelsman, J. Rules of engagement: Interspecies interactions that regulate microbial communities. Annu Rev Microbiol 62, 375-401 (2008).

123 Hooper, L. V. Do symbiotic bacteria subvert host immunity? Nat Rev Microbiol 7, 367-374 (2009).

124 Janzen, D. H. in The biology of mutualism (ed D.H. Boucher) 40-99 (Oxford University Press, 1985).

125 Kurkcuoglu, S., Degenhardt, J., Lensing, J., Al-Masri, A. N. \& Gau, A. E. Identification of differentially expressed genes in Malus domestica after application of the non-pathogenic bacterium Pseudomonas fluorescens Bk3 to the phyllospere. J Exp Bot 58, 733-741 (2007).

126 Haas, D. \& Defago, G. Biological control of soil-borne pathogens by fluorescent Pseudomonads. Nat Rev Microbiol 3, 307-319 (2005).

127 Guarner, F. \& Malagelada, J. R. Gut flora in health and disease. Lancet 361, 512-519 (2003).

128 Andrews, J. H. Biological control in the phyllosphere. Annu Rev Phytopathol 30, 603-635 (1992).

129 Vogel, C., Innerebner, G., Zingg, J., Guder, J. \& Vorholt, J. A. A forward genetic in planta screen for the identification of plant-protective traits of Sphingomonas sp. Fr1 against Pseudomonas syringae DC3000. Appl. Environ. Microbiol. 78, 5529-5535 (2012).

130 Hibbing, M. E., Fuqua, C., Parsek, M. R. \& Peterson, S. B. Bacterial competition: surviving and thriving in the microbial jungle. Nat Rev Microbiol 8, 15-25 (2010).

131 McCormack, P. J., Wildman, H. G. \& Jeffries, P. Production of antibacterial compounds by phylloplane-inhabiting yeasts and yeastlike fungi. Appl Environ Microbiol 60, 927-931 (1994).

132 Stromberg, K. D., Kinkel, L. L. \& Leonard, K. J. Relationship between phyllosphere population sizes of Xanthomonas translucens pv translucens and bacterial leaf streak severity on wheat seedlings. Phytopathology 89, 131-135 (1999).

133 Rouse, D. I., Nordheim, E. V., Hirano, S. S. \& Upper, C. D. A model relating the probability of foliar disease incidence to the population frequencies of bacterial plant pathogens. Phytopathology 75, 505-509 (1985).

134 Zamioudis, C. \& Pieterse, C. M. J. Modulation of host immunity by beneficial microbes. Mol Plant Microbe Interact 25, 139-150 (2012).

135 Kinkel, L. L. \& Lindow, S. E. Invasion and exclusion among coexisting Pseudomonas syringae strains on leaves. Appl Environ Microb 59, 3447-3454 (1993).

136 Stockwell, V. O., Johnson, K. B., Sugar, D. \& Loper, J. E. Control of fire blight by Pseudomonas fluorescens A506 and Pantoea vagans C9-1 applied as single strains and mixed inocula. Phytopathology 100, 1330-1339 (2010).

$137 \mathrm{Kim}, \mathrm{Y}$. C. et al. The multifactorial basis for plant health promotion by plant-associated bacteria. Appl Environ Microb 77, 1548-1555 (2011).

138 Teplitski, M., Warriner, K., Bartz, J. \& Schneider, K. R. Untangling metabolic and communication networks: interactions of enterics with phytobacteria and their implications in produce safety. Trends Microbiol 19, 121-127 (2011).

139 De Kempeneer, L., Sercu, B., Vanbrabant, W., Van Langenhove, H. \& Verstraete, W. Bioaugmentation of the phyllosphere for the removal of toluene from indoor air. Appl Microbiol Biot 64, 284-288 (2004).

140 Sandhu, A., Halverson, L. J. \& Beattie, G. A. Bacterial degradation of airborne phenol in the phyllosphere. Environ Microbiol 9, 383-392 (2007).

141 Leveau, J. H. \& Meyer, K. M. Microbiology of the phyllosphere: a playground for testing ecological concepts. Oecologia 168, 621-629 (2012).

142 Boch, J. et al. Identification of Pseudomonas syringae pv. tomato genes induced during infection of Arabidopsis thaliana. Mol Microbiol 44, 73-88 (2002). 
143 Tamir-Ariel, D., Navon, N. \& Burdman, S. Identification of genes in Xanthomonas campestris pv. vesicatoria induced during its interaction with tomato. J Bacteriol 189, 63596371 (2007).

144 Yang, S. H. et al. Genome-wide identification of plant-upregulated genes of Erwinia chrysanthemi 3937 using a GFP-Based IVET leaf array. Mol Plant Microbe Interact 17, 9991008 (2004).

145 Okinaka, Y., Yang, C. H., Perna, N. T. \& Keen, N. T. Microarray profiling of Erwinia chrysanthemi 3937 genes that are regulated during plant infection. Mol Plant Microbe Interact 15, 619-629 (2002).

146 Dulla, G. \& Lindow, S. E. Quorum size of Pseudomonas syringae is small and dictated by water availability on the leaf surface. Proc Natl Acad Sci USA 105, 3082-3087 (2008).

147 Newman, K. L., Chatterjee, S., Ho, K. A. \& Lindow, S. E. Virulence of plant pathogenic bacteria attenuated by degradation of fatty acid cell-to-cell signaling factors. Mol Plant Microbe Interact 21, 326-334 (2008).

148 Shepherd, R. W. \& Lindow, S. E. Two dissimilar N-acyl-homoserine lactone acylases of Pseudomonas syringae influence colony and biofilm morphology. Appl Environ Microbiol 75, 45-53 (2009).

149 Dulla, G. F. J. \& Lindow, S. E. Acyl-homoserine lactone-mediated cross talk among epiphytic bacteria modulates behavior of Pseudomonas syringae on leaves. ISME J. 3, 825-834 (2009).

150 Morohoshi, T., Someya, N. \& Ikeda, T. Novel N-acylhomoserine lactone-degrading bacteria isolated from the leaf surface of Solanum tuberosum and their quorum-quenching properties. Biosci Biotech Bioch 73, 2124-2127 (2009).

About the author

Julia A. Vorholt performed her PhD work at the Max-Planck-Institute of Microbiology in Marburg, Germany. She did a postdoc at the University of Washington, Seattle, USA and worked as a group leader at the CNRS in Toulouse, France. She is now Full Professor at the Institute of Microbiology, ETH Zurich, Switzerland. The research in her group is driven by her interest to learn how the environment shapes bacterial physiology, with an emphasis on metabolism, novel protein function and gene regulation. The habitat of particular interest to her is the phyllosphere.

HL refs

Lindow, S. E. \& Brandl, M. T. Microbiology of the phyllosphere. Appl Environ Microb 69, 1875-1883 (2003).

Excellent review summarizing earlier work on phyllosphere microbiology.

Leveau, J. H. J. \& Lindow, S. E. Appetite of an epiphyte: Quantitative monitoring of bacterial sugar consumption in the phyllosphere. Proc Natl Acad Sci USA 98, 3446-3453 (2001).

A seminal paper showing the heterogeneity of available fructose and/or sucrose on leaf surfaces.

Delmotte, N. et al. Community proteogenomics reveals insights into the physiology of phyllosphere bacteria. Proc Natl Acad Sci USA 106, 16428-16433 (2009).

This paper describes the application of a metaproteogenomics approach to analyse complex bacterial communities in the phyllosphere of three different model plants and reveals a high consistency among the communities suggesting unifying adaptive mechanisms among commonly found bacteria. 
Yang, C. H., Crowley, D. E., Borneman, J. \& Keen, N. T. Microbial phyllosphere populations are more complex than previously realized. P Natl Acad Sci USA 98, 3889-3894 (2001).

First cultivation independent study demonstrating that the diversity of phyllosphere bacteria is complex.

Knief, C., Ramette, A., Frances, L., Alonso-Blanco, C. \& Vorholt, J. A. Site and plant species are important determinants of the Methylobacterium community composition in the plant phyllosphere. Isme J 4, 719-728 (2010).

Comprehensive cultivation-independent study showing the importance of plant species and site for the community composition of ubiquitous Methylobacteria.

Redford, A. J., Bowers, R. M., Knight, R., Linhart, Y. \& Fierer, N. The ecology of the phyllosphere: geographic and phylogenetic variability in the distribution of bacteria on tree leaves. Environ Microbiol 12, 2885-2893 (2010).

This paper provides evidence for predictable bacterial phyllosphere community pattern in dependence of the relatedness of trees.

Melotto, M., Underwood, W., Koczan, J., Nomura, K. \& He, S. Y. Plant stomata function in innate immunity against bacterial invasion. Cell 126, 969-980 (2006).

This study shows the importance of coronatine produced by Pseudomonas strains to prevent PAMP/MAMP-triggered stomata closing.

Gourion, B., Rossignol, M. \& Vorholt, J. A. A proteomic study of Methylobacterium extorquens reveals a response regulator essential for epiphytic growth. Proc Natl Acad Sci USA 103, 13186-13191 (2006).

This study describes together with reference 108 the discovery of the PhyR-NepR-SigmaEcfG signaling cascade that is crucial for epiphytic fitness of phyllosphere bacteria and governs the general stress response in Alphaproteobacteria.

Beattie, G. A. Water relations in the interaction of foliar bacterial pathogens with plants. Annual Review of Phytopathology 49, 533-555 (2011).

This review provides an integrated summary on various aspects and consequences of water availability for microorganisms in the phyllosphere.

Monier, J. M. \& Lindow, S. E. Differential survival of solitary and aggregated bacterial cells promotes aggregate formation on leaf surfaces. Proc Natl Acad Sci USA 100, 15977-15982 (2003).

This paper shows the importance of aggregate formation of a phyllosphere bacterium for tolerating environmental stresses using epifluorescence microscopy.

Blanvillain, S. et al. Plant carbohydrate scavenging through TonB-dependent receptors: A feature shared by phytopathogenic and aquatic bacteria. Plos One 2, e224 (2007).

A comprehensive study that puts forward the hypothesis on the importance of TonB-dependent receptors as transporters for uptake of various carbohydrates under environmental conditions.

Quinones, B., Dulla, G. \& Lindow, S. E. Quorum sensing regulates exopolysaccharide production, motility, and virulence in Pseudomonas syringae. Mol Plant Microbe In 18, 682-693 (2005).

Ref. 115 and 116 demonstrate the importance of quorum sensing for epiphytic fitness of Pseudomonas syringae, while ref. 146 shows induction of the system under in situ conditions in dependence of aggregate size.

At a Glance Summary 
* The surface area of the phyllosphere is approximately twice as great as the land surface area and provides a habitat for numerous microorganisms, which colonize the surfaces (where they mostly form aggregates) and the inside of leaves.

* Most phyllosphere microorganisms are bacteria, are non-pathogenic and belong to a few predominant phylogenetic groups including Alpha-and Gammaproteobacteria, Bacteriodetes and Actinobacteria. The fungi that are also detected in the phyllosphere appear hyperdiverse.

- Numerous abiotic and biotic factors drive the microbial community structure in the phyllosphere, including the plant itself.

* Targeted and large scale metaproteogenomic studies have helped to identify important mechanisms by which bacteria adapt to the phyllosphere; among these are aggregate formation, surface alterations by production of biosurfactants, induction of stress responses and metabolic adaptations ranging from utilization of the one carbon compound methanol to amino acids and sugars.

* The phyllosphere is a discrete habitat (a sum of discrete habitats) and is a tractable model system for understanding the relationships between microorganisms and hosts. An improved understanding of phyllosphere microbiology is also of practical importance for biocontrol of the phyllosphere as the primary carbon fixing unit in terrestrial systems. 